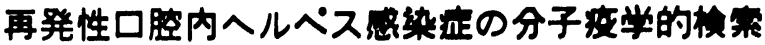

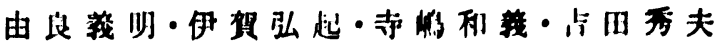

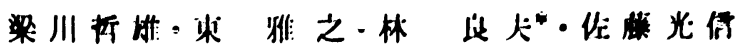

\section{Molecular epidemiological study of recurrent intraoral herpes simplex virus infection}

\author{
Yoshiaki YURA - Hiroki IoA - Kazuyoshi Terashima \\ Hideo Yoshida - Tetsuo Yanagawa - Masayuki AzUma \\ Yoshio HaYashi* - Mitsunobu Sato
}

\begin{abstract}
Recurrent intraoral herpes simplex virus infection, which was first deacribed by Griffin in 1965, is an uncommon type of herpes simplex virus (HSV) infection. To determine whether this is caused by reactivation of HSV in the oral cavity latently infocted with HSV,we isolated the viruses from primary and recurrent lesions of intraoral HSV infection in the same patient and analyzed the DNA of the isolated HSV viruses.

A 48-year-old woman came to our clinic on July 15, 1982 with severe pain in the oral cavity. On examination, numerous ulcerative lesions were observed in the mucos of lower alveolus and hard palate. HSV was isolated by tissue culture work from the swab of lesions. Although the antibodies against HSV were not detected by complement-fixation test in the serum harvested from the patient at acute phase of the disease, the titer was increased to $\times 16$ at the convalescent stage. Therefore, it was diagnosed as a primary herpetic gingivostomatitis. This disease was healed completely by topical administration of interferon- $\beta$. About 11 months later, ulcerative lesions occurred again in the lower gum and were treated with interferon- $\beta$. Virus was isolated from the lesions and proved to be HSV as demonstrated by a fluorescent antibody staining method for HSV antigen.

The two isolates obtained at different time from this patient, including standard HSV type 1 and 2, were grown in Vero cells. DNA was extracted from the infected cells according to the method of Hirt and was digested with various restriction endonucleases. The DNA fragments were submitted to agarose gel electrophoresis, stained with ethidium bromide and then the electrophoretic patterns were observed under UV illumination. The cleavage pattern of DNA from all the HSV isolates was found to be similar to that of HSV type 1, but not to the HSV type 2. Therefore, these isolates can be considered to be HSV type 1. Moreover, the two viruses isolated from the present case gave almost same DNA cleavage pattern. From these findings, it can be concluded that the intraoral HSV infection which occurred after
\end{abstract}

徳島大学齿学部口腔外科学第 2 撞座 （主任：佐藤光信救授）

* 徳島大学齿学部附属病院中央检査室 （主任：林 良夫室長）

The Second Department of Oral and Maxillofacial Surgery, Tokushima University, School of
Dentistry (Chief: Prof. Mitsunobu Sato)

* Central Laboratory for Clinical Investigation, Tokushima University, School of Dentistry (Chief: Yoshio Hayashi)

受付日：昭和60年 2 月 12 日 
complete remission of the primary HSV infertion in the present cise is caused by the sime virus, implying that the second onset of intraoral IISV infection is of rocurent lorm.

Key words: herpes simplex virus, recurrent intratoal lesion, molecular epidemiology

\section{緒言}

単純ヘルペスウィルス（以下 HSV’上略記）は，特も に顔面，口腔に感染する1型と性器に㷂染する2型とに

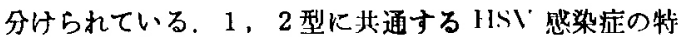
徵は，初慰染症状が消退したのちも生体内にウイルスが

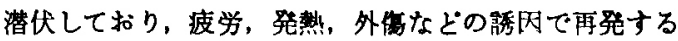

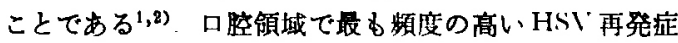
は口唇へルベスであるが，口腔战膜に限局して再発性病 変の生ずることが知られるよらになっている3 疾患は，Griffin ${ }^{3)}$ か 1965年口腔内潰場病变に HSV 抗原 を袷出することで存在を明らかにした比較的新しいもの である.病名である recurrent intraoral herpes simplex virus infection に相当する用語は統一されていないため， 本報告では再発性口腔内人ルベス感染症と呼ぶことにす 万.

本疾患は，HSV 初感染時のごとく全身症状を伴うこ とは少なく、アフタ性口内炎など口腔粘膜に糜爛や謴癔 を形成する疾患との鑑別が困難で，ウイルス分離あるい は，病変細胞にウイルス抗原を検出することによって初 めて診断が下せる、したがって確定診断のついた症例は いまだ少ない。

再発性へルベスは，初感染ののち神経節に潜伏した HSV が，何らかの誘因で再活性化され神程軸索に沿っ て末梢に達し，上皮細胞で增殖することにより発症する と想像される，しかし，最近開発されたウイルス DNA の制限酵素切断パターンを比較する，いわゆる分子疫学 的手法を用いることにより，HSV の初感染領域に他の HSV の再感染し5ることが証明されている め，HSV による再発性病変は，潜伏ウイルスの再活性 化だけでなく，外因性ウイルスの再感染によって起こる 可能性もある。

過去に拉ける再発性口腔内へルペス感染症の報告で， 再感染を念頭に入れてその発症機序を検討したむのはみ られない，そこで，本研究で，この疾患が再活性化か 他のウイルスによる再感染かを明らかにするため，同一 患者の初感染と再発時に分離した HSVにつき, 分子疫 学的検索を行った，症例の概要とウイルス DNA 分析結 果を報告する.

\section{症}

\section{例}

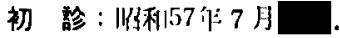

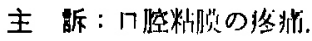

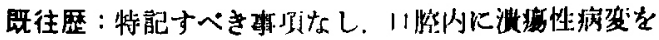
生じたことはなく，生た恬ールベスの既往すなかっ た.

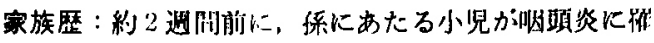
岕していた。

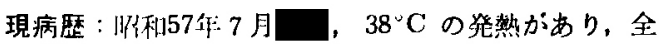
身倦急感を生じた，某内科にて投薬を受け下熱したが， 口腔内に自発痛を認めるよらになった。そのため，食事 摄取が困難となり，補滩と抗生郕投与を受けた。目腔内 に生した瀢疡性病変には，薬剂登布が続けられたが症状 の改善がみられず，発症 5 日後に，当科を受診した。

現 症：体格，栄意ともに中等度で, 顔面ならびに全

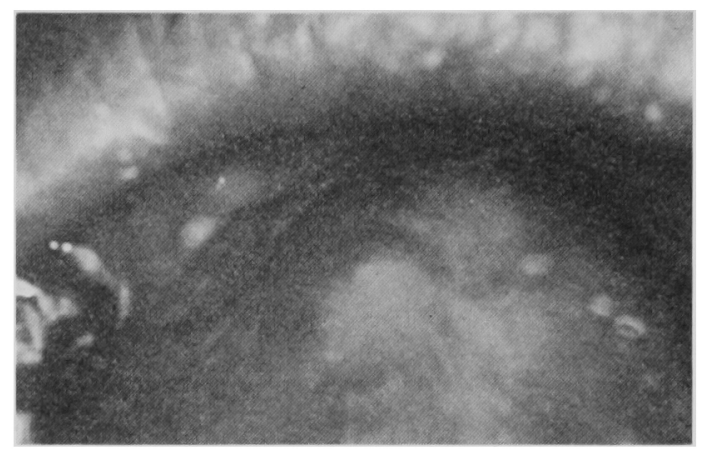

写真 1 初診時, 口空内所見 (1) 口蓋粘膜に糜燘と白色苔の付着した小䟺瘍が散在し ている。

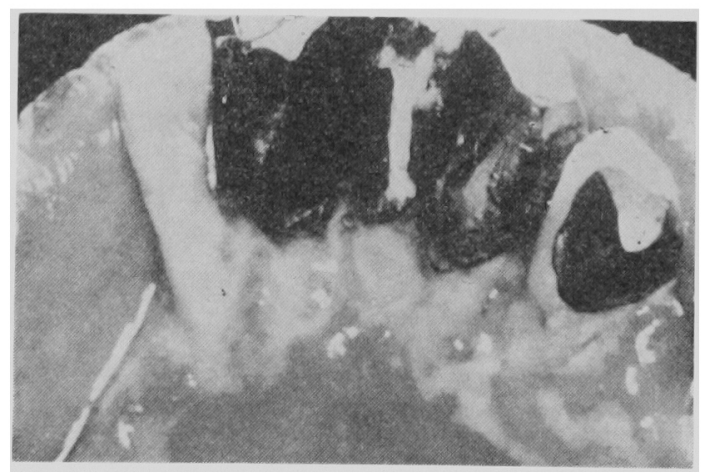

写真 2 初診時, 口宾内所見 (2)

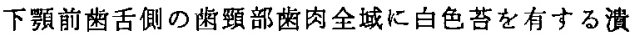
曒が認められる。 


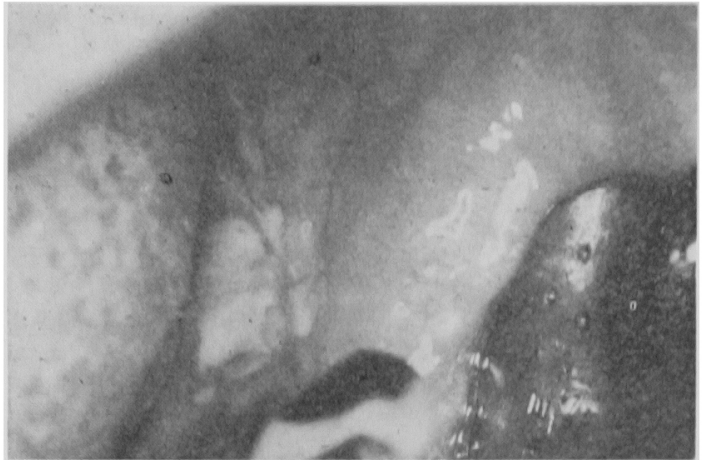

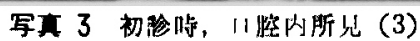

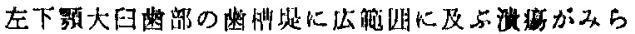
机为。

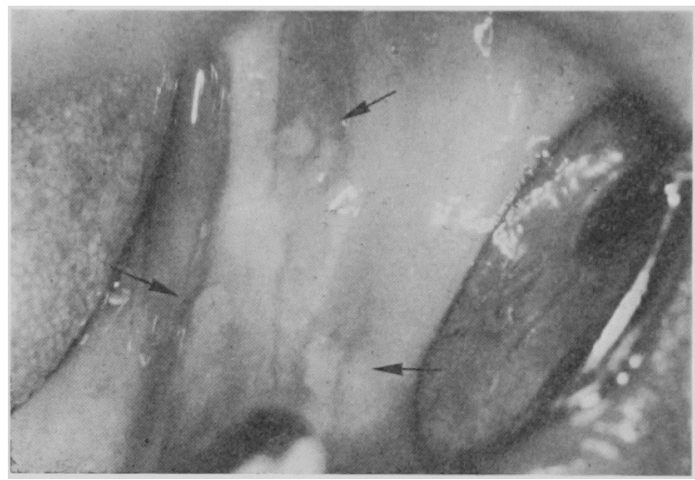

写真14三再発性病变出現時, 口腔内所見

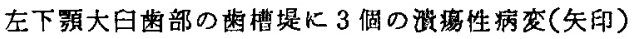
がみられる。

身の皮膚に発㡎，水抱等の異常は認めなかった。領域り ンパ節所見として，両側の顎下りンハ節は，小指頭大て 各 1 個触知し, 弾性硬, 軽度压痛を認めた。

口腔内所見：雪牙は下顎前歯部之上顎田曾部以外は久 損しており，残存寸る前柬る動摇が認ぬられた。欠損部 歯槽堤，残存菌牙の歯肉部および硬口蓋部の粘膜は発赤 して敊り，表面に白色苔の付着した多数の潰瘍性病变が 認められた（写真 1 亿).

臨床検查所見：初診時の血液検查の結果, 白血球数 $8,000 / \mathrm{mm}^{3}$, 赤血球数 $498 \times 10^{4} / \mathrm{mm}^{3}$, へモグロビン值 $15.5 \mathrm{~g} / \mathrm{d} l$, ヘマトクリット值 $48.4 \%$ ，血小板数 $24.1 \times$ $10^{4} / \mathrm{mm}^{3}$ で，白血球増多症はみられなかった。トラン スアミナーゼをはじめ，血液化学検查值は正常䇛囲内て あった。 CRP 值は 4 十、赤血球沈降速度は 1 時間值で $62 \mathrm{~mm}$ と元進 していた，免疫グロブリン值は，IgG $1,830 \mathrm{mg} / \mathrm{d} l, \operatorname{IgA} 305 \mathrm{mg} / \mathrm{d} l, \operatorname{IgM} 96 \mathrm{mg} / \mathrm{d} l$ で異常は みられなかった，尿検查では，蛋白 1 十，アセトン体 $1+$ 十゙あった。

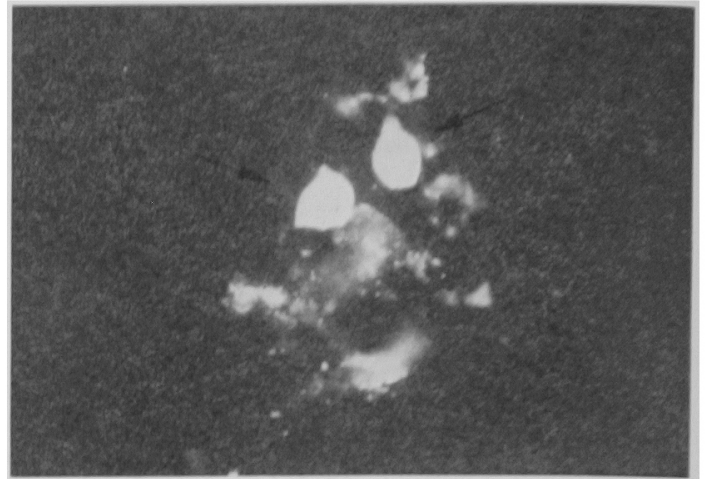

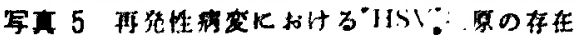

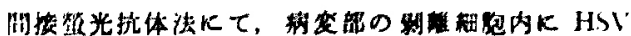

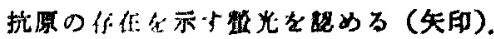

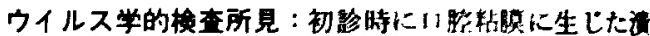

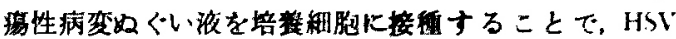
が分離された，初診時採取した血清中のHふに祄する 補体結合抗体価は 4 倍以下であり，㟶出されなかった。

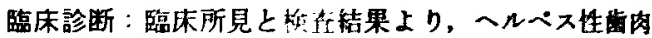
口内炎と診断した。

処置ならひに再無性病変出現むでの経過：7月几

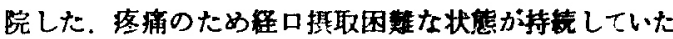
ので，補液，ビタミンB数合用の投与を行った，細菌に よる重感染䂆防の目的で，液内に抗生淜セフっレキシ

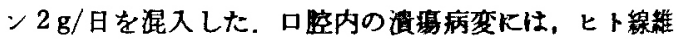
芽緗胞を poly 1 : poly C で処理して調製したインタ

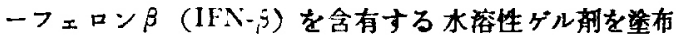

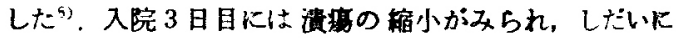
释口提取可能となったため 7 日目に退院した。病贺は初

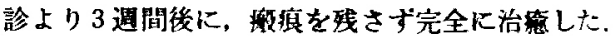

HSV 再発性病变の出現時所見：へルベス性柴肉口内 炎を発症した初診時より的 11 か月绻の昭和 58 年 6 月 口，左下額曰齿に刺敏痛を覚えたため，6月、に当科

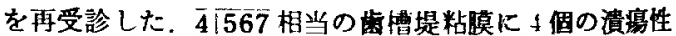

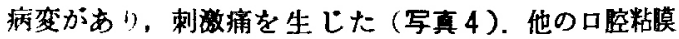
ならびにロ唇に異常はなく，願下ッンバ節は両側とる小 指頭大で 1 個触知し王痛は鮥めなかった，前回と同様に

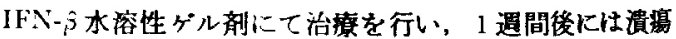
性病変の完全な消退をみた，この病変が HSV感染によ るか否かを知るため，ウイルス学的検索を行った。すな わち，病変部よりのウイルス分蜼と病变部制噰紐胞に対 し，抗 HSV 1 型家鬼 IgG, FITC 結合抗家鬼 IgG ブ 夕血清 (Dakopatts 社製) を用いる間接蛨光抗体法にて, $\mathrm{HSV}$ 抗原の検出を試子た。 その結果，HSVが分離で

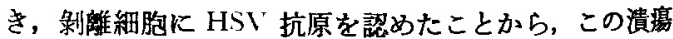
性病変は，HSVによることが明らかとなった(写真 5). また，HSV に対する補体結合抗体価は16倍であった。 
以上より，初猃時は，HSI の初留染によるへルベ 性齿肉口内炎であり，11か月後に生した病変汢，垭発俳: 口腔内へルペス感染症と誩断した。

\section{分離ウイルス DNA の制限醉素切断 パターンによる比較検討}

\section{1. 研究材料と方法}

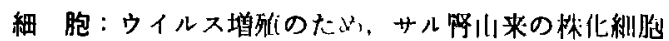

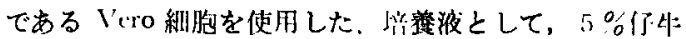

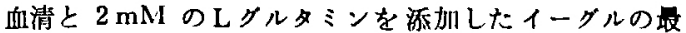

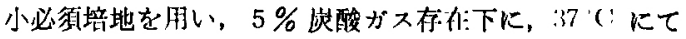
培買した。

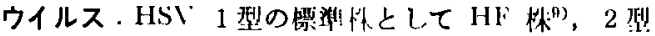

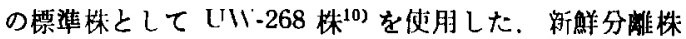

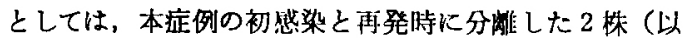
下 Ym-1 と Ym-2 と略記) 以外に，別の成人一ルペス性 第肉口内炎 2 症例より分離 した HSV（以下 Tj と To と 略記）を用いた。

ウイルス DNA の抽出：Hirt"1)の方法に準じて以下の ごとく行った. Vero 緗胞 $\left(4 \times 10^{7}\right)$ に, $4 \times 10^{7}$ プラッ ク形成能を有するウイルスを接種し， $37^{\circ} \mathrm{C}$ にて培羕し た８0９0\%の細胞にウイルス増殖に伴ら変性が友られ た時点で, 培養液を除去し，0.6\% sodium dodecyl sulfate (SDS), 0.01M の EDTA を含む $10 \mathrm{mM} ト$ リー 塩酸湩液 ( $\mathrm{pH} 7.5) 4 \mathrm{ml}$ にて感染紏胞を溶解した。 1 時間 $37^{\circ} \mathrm{C}$ に加温したのち, $5 \mathrm{M}$ の $\mathrm{NaCl}$ を $1 \mathrm{ml}$ 加 克，緩徐に混和し， $4^{\circ} \mathrm{C}$ にて12時間静置した。 $17,000 \times$ gで30分間遠心し，染色体外 DNA に相当する上清を採 取し，これに $1 / 20$ 量の $20 \times \mathrm{NTE}$ 緩衝液(NTE: $0.1 \mathrm{M}$ $\mathrm{Nacl}, 0.01 \mathrm{M} ト$ トスー $\mathrm{NCl}, \mathrm{pH} 7.4,0.001 \mathrm{M}$ EDTA) を加えた. Protease (sigma 社製) $500 \mu \mathrm{g} / \mathrm{ml}$ を 37 C で 4 時間反沁させ混入した蛋白を分解したのち，水䬷和フ ェノール, 次にクロロフォルムとインフミールアルコー ル（24:1）にて DNAを抽出した。2 倍量の95\%ェタ ノールを加えて DNA を沈澱させ，1/10 NTE 楥衝液に 溶解した. $50 \mu \mathrm{g} / \mathrm{ml}$ の RNase (Sigma) にて RNA を 分解したのち最終的に 1/10 NTE 緩街液に DNA を溶 解し, OD 260 の吸光度で定量した。

DNA の制限酵素による切断と電気泳動：ウイルス DNA (3-5 $\mu \mathrm{g})$ を制限酵素である BamH I, Kpn I ,

Sal I (宝酒造社製) にて切断した，反応条件は酵素に より異なり，BamH I では, $10 \mathrm{mM}$ Tris- $\mathrm{HCl}, \mathrm{pH} \mathrm{8.0,}$ $7 \mathrm{mM} \mathrm{MgCl}_{2}, 100 \mathrm{mM} \mathrm{NaCl}, 2 \mathrm{mM} 2$-メルカプトェタ ノール, 0.01\%ウシ血清フルブミン, Kpn I では $6 \mathrm{mM}$ Tris- $\mathrm{HCl}, \mathrm{pH} 7.5,6 \mathrm{mM} \mathrm{MgCl}, 6 \mathrm{mM} \mathrm{NaCl}, 6 \mathrm{mM}$ 2一メルカプトェタノール，0.02\%ウシ血清アルブミン， Sal I では, $10 \mathrm{mM}$ Tris- $\mathrm{HCl}, \mathrm{pH} 7.5,7 \mathrm{mM} \mathrm{\textrm {MCl } _ { 2 }}$, $175 \mathrm{mM} \mathrm{NaCl}, 0.2 \mathrm{mM}$ EDTA, $7 \mathrm{mM} \mathrm{2-メルカプト}$

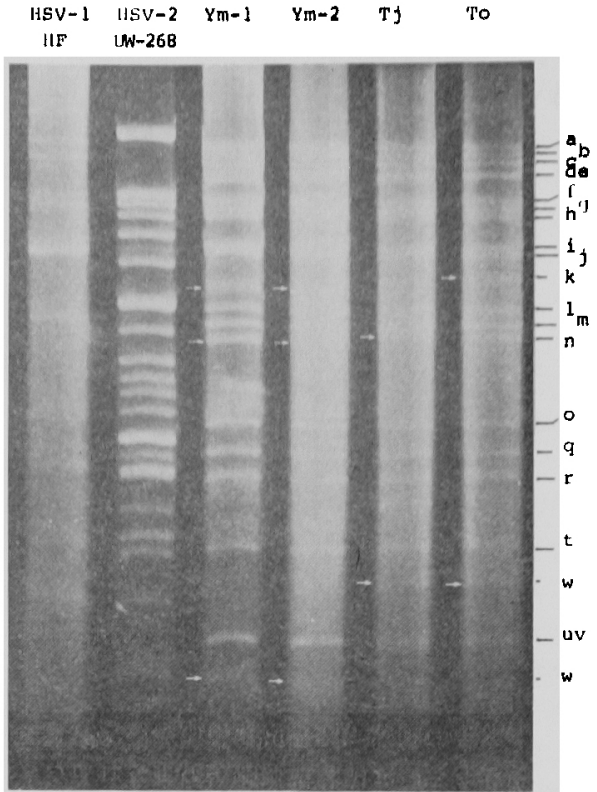

写氠 6 制限醭案 BamH I によるウイル ス DNA 七刀断バターン

HSV 1 型 (HF 株), HSV 2 型 (UW-268 怢)，本症例の分離株 ( $\mathrm{Ym}-1, \mathrm{Ym}-2)$, 他 の 2 症例上りの分離怢 $(\mathrm{Tj}, \mathrm{To})$ 加茼紫 したウイルス DNAを BamH I で切断し， その切断片を同时にフガローズゲル電気泳 動した。アルファペットはDNA 断片名を 示し，矢印は快症例と他の症例上りの分離 株間で DNA 断片の移動度に差のみられる 筒所を示している。

エタノール, $0.01 \%$ \%ウ血清アルブミンを含む溶浓中で, $37^{\circ} \mathrm{C}$ にて 6 時間反応させた，1/10 量の反応停止液 (50 \%グリセロール， I \% SDS, 0.02\%ブロムフェノールブ ルー）を加え， 37 Cで 10 分間保温した，電気泳動用の フガローズゲル浱庭は $0.9 \%$ で㣪衝液として $90 \mathrm{mM}$ Tris-HCl, pH 8.3, $90 \mathrm{mM}$ 木ウ酸, $2.5 \mathrm{mM}$ EDTA を 含む溶液を用いた。制限酵素で切断した DNA 断片を50 $\mathrm{V}$ て $12 \sim 15$ 時間電気泳動したのち， $0.5 \mu \mathrm{g} / \mathrm{ml}$ のエチ シウムブロマイドで染色し，UV ライト照射下に観察し た。

\section{2. 結 果}

HSV 1 型と 2 型の䧣準株，本拝例の初感染と再発時 に分離した $\mathrm{Ym}-1$ 之 $\mathrm{Ym}-2$ ，他の患者より分離した $\mathrm{Tj}$ と To の計 6 株について,ウイルス DNA を調製し制限 酵素 BamH IKて分析した（写真 6)．DNA 断片をア ガローズゲル電気泳動すると小さな断片はど速く移動す るので, 写真では下方に配列することになる. DNA 断片 は, サイズの大きいあのから順に Sakaoka ${ }^{12)}$, Locker ${ }^{(3)}$, 
$Y m-1 \quad Y m-2 \quad Y m-1 \quad Y m-2$

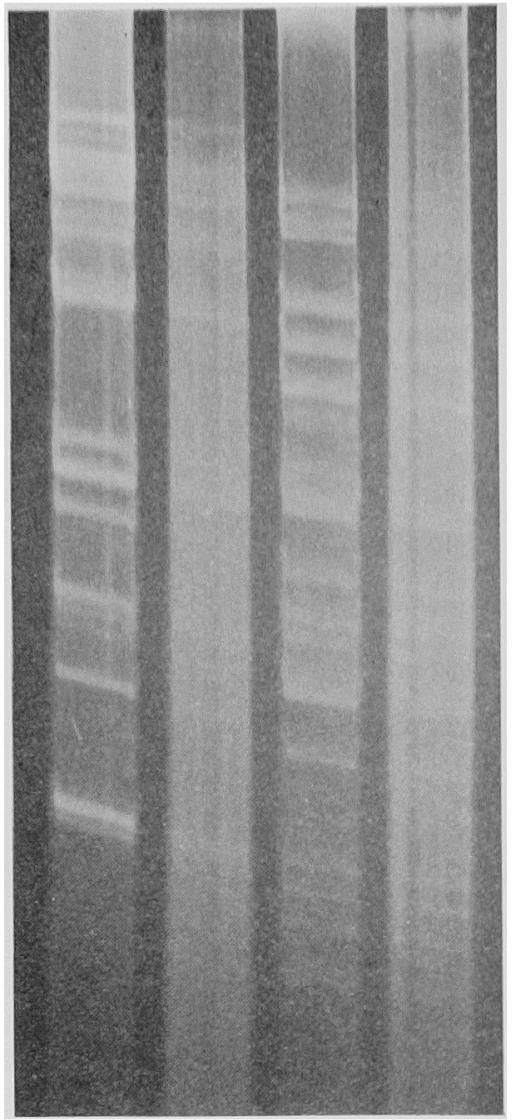

Kpn I

Sal I

写真 7 制限醇奖 Kpn I， Sal I よるウイルス DNA 切断ハタ ーン

本症例の分離株 $\mathrm{Ym}-1, \mathrm{Ym}-2$ 上り调 製したウイルス DNAを Kpn I ある いはSal Iにて切断し，その DNA 切 断片を同時にアガローズゲル雪気泳動 した。

$\mathrm{Ueno}^{14)}$ らの報告に従って，a，b，cと標記した。䉓 気泳動バターンを比較したところ，本症例を含む新鮮分 離株は，2 型標準株とは全く異なっておりりすぺて HSV 1 型と決定された。さらに，本症例より分離した Ym-1 と Ym-2 は同一のハターンを示すのに対し, 他の患者由 来の $\mathrm{Tj}$, To とは部分的に異なって扰り，1型内での株 間の差を明らがすることができた。

Ym-1 と Ym-2 は，BamH I 醅素を使用した場合きわ めて類似した切断バーンを示したが，DNA の差は複 数の酵素による検索で初めて検出できる可能性もあるた

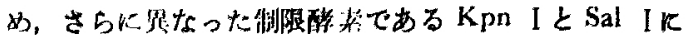

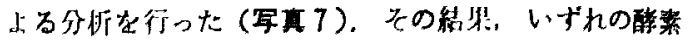
な们用してい町断ハターンは弣一であった，したがって

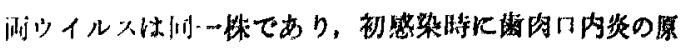

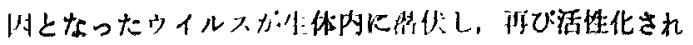

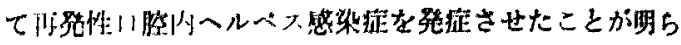
ふとなった。

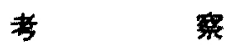

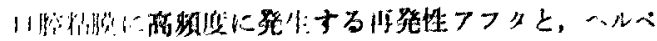

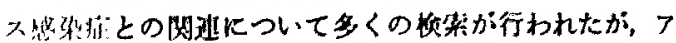
フタよりHSVは分離されナ゙，その园進性は否定され $た^{|5,16\rangle}$ ，そのため，一般に口拄路城での HSV の再発性

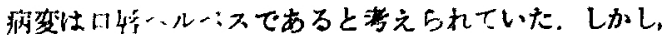

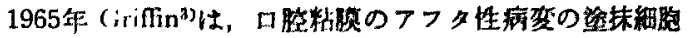

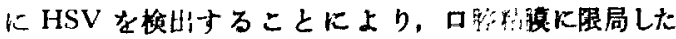

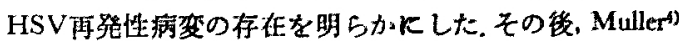

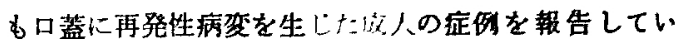

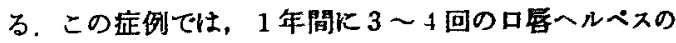
再発がみられ，血清中 HSV のに対する補体結合抗体值 は高值を示した。これらは，䂞へルベスの睡往があり， 口腔内に再発性へルペスを生じた症例であった。 われか れの程験した症例は，初診時ウイルスが分離されたにる かかわらず，HSV に対する抗体が全く模出されず，回 復期になって初めて抗体洒の上算を放めたことから， HSV 初感染と考えられた。惑染释路については不明て

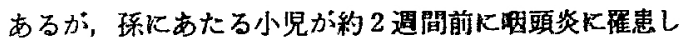
たとのことで，この小睍よりウイルスの层播した可能性

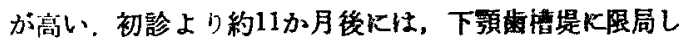
$\tau$ HSV 再発性病变が出現し，この部位より HSV が分 離され，制雄細胞に HSV 抗原が换出された。したがっ

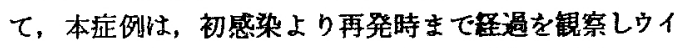
ルス学的検索を加えることのできた貴重な再発性口踥内 ヘルベス感染症の莚例といえる。充た，本症例では口唇 ヘルペスを経験しておらず，再発時口唇に異常は認めな かった，そのため，再発性口腔内一心ベス感染㱏は，口 唇へルベスとは䦎連を持たずに発症し5るるのと思われ ๖.

ロ唇へルペスに比較して，なぜ再発性口腔内へルベス 感染症の症例が少ないかは明らかでないか，唾液中の非 特異的なウイルスのインヒビタ一や HSV に対する分泌 型 IgA 抗体が， 口膑粘膜での HSV 感染症の防止に役 立っていると思われる4,17．あるいは，症状が軽度のた め患者に気付かれずに治㤪している病変が多いのかるし れない28).

再発性口腔内へルペス感染症の発症機序については, 三叉神経節に潜伏する初感染ウイルスが再活性化するこ と以外に，別の HSV による口腔粘膜への再感染の可能 


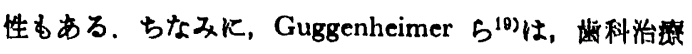

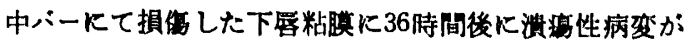
出現し, 病変部より HSV が分離されたと報告してい る.この患者は過去にロ唇へルベスの既往はあるが，口 腔粘膜に溃瘁性病変を生じたことはなかった，彼らは， 損傷した粘膜に同じ患者の唾液あるいは咽䫒分泌物中に 含まれていた HSV が再感染したのではないかと考えて いる．また，ウイルスの再感染を示す知見として，取近， Lewis らクによって興味深い報告がなされている，彼ら は，尾体より得た三叉神経節と神経根を in vitro で培堭 して潜伏する HSV の再活性化をはかったところ，HSV 1 型の複数の株が分噰された，すなわち，同じ口腔領域 です異なった HSV 1 型が再感染して，神释組䅧に潜伏 することが示晙されたわけである。ささらに, Buchman らの゙は, 同一個体の性器から異なった HSV 2 型の分離 されたことを報告している．したがって，再発性口腔内 ヘルペス感染症についても，HSV 再感染にて発症する ことを十分考秃に入れる必要があり, 初感染ウイルスの 再活性化であって他のウイルスの再感染でないことを証 明するには，分離ウイルスが初感染と再発時とで同一で あることを同定しなければならないことになる。

分離した HSV の同定は, 必ずしむ容易であるとはい えない. 型决定の䏅には, ウイルスのニワトリ胎児細胞 と㸛尿膜での増殖能やブラック形成能の差 ${ }^{20)}$ ，温度に対 する感受性 ${ }^{21)}$, 感染細胞での核内 microtuble 出現の有 無22)などが利用されている.最も一般的な型決定法は，1 型と 2 型に対する特異抗体のいずれによって,よりウィ ルス感染力価が低下するかを検索する中和試験である. この方法の問題点としては, 1 型と 2 型とでウイルス構 成蛋白が共通するため使用する抗体によっては，必ずし る明膫な判定を下しえない場合のあることである゙3)。 たこれらの検査法では, 型の同定は行えても同一型内 での株間の差を明らかにし，ウイルスを分類すること はできない.ウイルス株間の差を検出する方法として は，現在までにウイルス蛋白とウイルス DNA を分析す る検査法が検討されている. Pereira ら HSV 1 型ウイルスの構成蛋白を SDS-ポリアクリルアミ ドゲル電気泳動にて分離し，その移動度の差をおのおの の株間で比較した．その結果19のクルルーブに分類できた としている.しかし，この方法は手技が煩雑でアィント ーブが必要であり，臨床検査には応用し難い点が多い。

これに対し，ウイルス DNA を制限酵素で切断しその電 気泳動ハターンを検討する方法は，比較的容易にウイル ス間の差を検出できることが報告されている12 14,25).

HSV の遗伀情報をになう核酸は，分子量が 85-100 $\times 10^{6}$ ダルトンの線状二重鎖 DNA で，その $82 \%$ を占め るL 部分と $18 \%$ を占める $\mathrm{S}$ 部分より成り立っている ${ }^{25)}$. $\mathrm{L}$ と S 部分の両端に存在する倒置反復配列部は, 制限酵 素による切断の際変化しうるが，Lと S の特異部分は同
一株内できわめて安定である，そのため，ウイルスの杯

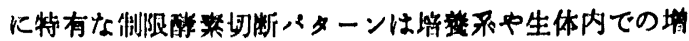
殖の後む交化することがなく，HSV の型分類や株网の

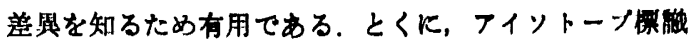
しないHSV 憼染絒胞より抽出した全細胞 DNA を用い ても、ウイルスの DNA の切断バターンを知ることがで き12,14)，撸作はより简使となっている，ウイルス DNA の执出法としては，柋染細胞より全紐胞 DNA とウイル ス粒子より DNA を得る方法が一般的に用いられてい る.しかし、ウイルス以外の細胞 DNA の混入ゃ，ウイ ルス精製操作の煩雑さなどの间題点がある。本研究で は、ボリオーマウイルス感染細胞より值接ウイルス DNA を抽出する Hirt"1)の方法に洋じて，HSVの DNA を协 率よく抽出でき，良好な成籍を収めることができた，今 後，臨床検查レペルです応用可能な方法と考える.

われわれが，Hirt 法にて調製した DNA を BamH I にて切断し，泳䡃ハターンを検討した結果，1種類の醇 素を用いるたけげ十分に型の判別を行うことがでさ，さ らに 1 型内での株間の差を検出することができた．酵素 としては，DNA を適当な断片に切断する特性を有した ものを選択する必要があり, HSV の场合, BamH I， Kpn I，Sal I は有用な酵素であった，2種の株の同一 性を強く示唆するためには，2つ以上の醳素で検索する 必要があるが，本研究では，上記の 3 種類の酵素で同じ 切断ハターンが得られたことから，初感染と再発時に分 離されたウイルスは同一株と考えられた。

再発性口腔内へルペス感染症は，明確な診断の下され た症例の少ない疾患であり，その発生頻度についてもい まだ明らかにされていない，過去に拈ける報告では，病 変よりのウイルス分㸕, ウイルス抗原の検出，抗体価の 測定は行われている3,4). しかし，技術的に困難なことか ら, 再発性病変がウイルスの再活性化か再感染のいずれ により生じたかの検索は行われていない. そのため, われわれが経験した症例は，再発性口腔内ヘルペス感染 症が初感染ウイルスの再活性化により発症したことを遗 伝子レベルで解析できた取初の症例と思われる。

近年, 口腔と性器との間で HSV の伝播することが知 られており，性器から1型あるいは口腔から2 型が分離 されたとの報告もみられる26,27)。 また，HSV が睡液に 混入し不影性に排泄される口腔内に手指を入れる崡科医 では，ヘルペス性瘵疽の䍜患率が有意に高く28,29), 齿科 医療従事者と患者との間で，手指を介してへルペスが伝 播する危険性も指摘されている。しかし，HSV 云播経 伝路は追跡が困難であり，大部分が不明のままである. 今後, 本研究で述へたた分子疫学的手法を用い発病の原因 ウイルス株を同定することにより，HSV 伝播経路の 解 明と感染の予防・阻止が可能になると思われる. 


\section{結}

\section{6}

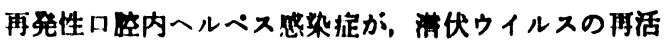
性化に上るか，他のへルペスウイルスの同恕架によるか， を知るため，同一㱏例において初感架と再発時病变上り 分崔した 2 株のウイルスにつき，分子文学的厅渚を用い

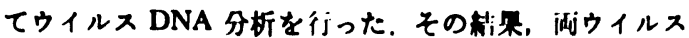
は同一判と明し，本应例の再発性病变は，初感染のの

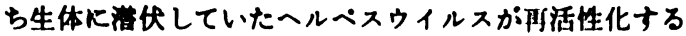
ことで生じたるのと考えられた。

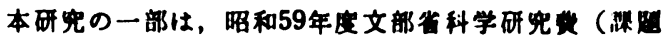
番号59480393と59771524）の报助をけて受けった。

\section{引用文 敨}

1) Mandell, G.L., Douglas, R.G., et al.: Principles and Practice of Infectious disease. vol. 2 John Wiley \& Son, New York, 1979, p 12831294.

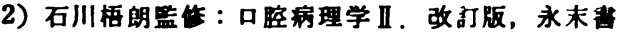
店, 京都, 1982，128-130面。

3) Griffin, J.W.: Recurrent intraoral herpes simplex virus infection. Oral Surg 19: 209-213 1965.

4) Muller, S.A.: Recurrent herpes simplex of the hard palate. Arch Dermatol 98: 273-276 1968.

5) Sheridan, P.J. and Herrman, E.C.Jr.: Intraoral lesions of adults associated with herpes simplex virus. Oral Surg 32: 390-397 1971.

6) Buchman, T.G., Roizman, B., et al.: Demonstration of exogenous genital reinfection with herpes virus type 2 by restriction endonuclease fingerprinting of viral DNA. J Infet Dis 140: 295-304 1979.

7) Lewis, M.E., Leung, W.C, et al.: Detection of multiple strains of latent herpes simplex virus type 1 within individual human hosts. J Virol 52: 300-305 1984.

8) Sato, M., Yoshida, H., et al.: Therapeutic effect of human fibroblast interferon on premalignant lesion arising in oral mucosa: A pilot study. Int J Oral Surg 14: 184-194 1985.

9) Wheeler, C.E.: The effect of temperature upon the production of herpes simplex virus in tissue culture. J Immunol 81: 98-106 1958.

10) Wentworth, B.B., French, K.: Plaque assay of herpes virus hominis on human embryonic fibroblasts. Proc Soc Exp Med 131: 588-592 1969.

11) Hirt, B.: Selective extraction of polyoma DNA from infected mouse cell cultures. J Mol Biol 26: 365-369 1967.

12) Sakaoka, H., Aomori, T., et al.: Restriction endonuclease cleavage analynis of herpes simplex virus isolates obtained from three pain of siblings. Infect Immun 43: 771-774 1984.

13) Locker, H., Frenkel, N., et al.: Bam I, Kpn I, Sal I restriction enzyme maps of the DNAs of herpes simplex virus strains Justin and F: Occurrence of heterogeneities in defined regions of the viral DNA. J Virol 32: 429-441 1979.

14) Ueno, T., Suzuki, N., et al.: A simple and practical method for typing and strain differentiation of herpes simplex virus using infected cell DNAs. Microbiol Immunol 26: 1159-1170 1982.

15) Blank, H., Burgoor, C.F., et al.: Recurrent aphthous ulcers. JAMA 142: 125-126 1950.

16) Griffin, J.W.: Fluorescent antibody study of herpes simplex virus lesions and recurrent aphthae. Oral Surg 16: 945-952 1963.

17) Tokumaru, T.: A possible role of gammaimmunoglobulin in herpes simplex virus infoction in man. J Immunol 97: 248-259 1966.

18) Scott, T.F.M.: Acute infectious gingivostomatitis. JAMA 177: 999-1005 1941.

19) Guggenheimer, J., Ronald, D., et al.: Traumatic induction of an intraoral reinfection with herpes simplex virus. Oral surg 38: 5465491974.

20) Rodgers, F.G.: Growth of herpes simplex virus type 1 and type 2 in tissues of fertile hen's cggs in vivo and in vitro. Br J Exp Path 63: 3173221981.

21) Ratcliffe, H.: The differentiation of herpes simplex virus type 1 and type 2 by temperature markers. J gen Virol 13: 181-183 1971.

22) Ishida, N.: Differentiation of herpes simplex virus type 1 and 2 by intranuclear structures in clinical infection. Microbiol Immunol 25: 847-851 1981.

23）川名林治，佐藤成大，他：単杶へルベスゥイル

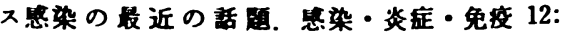
133-141 1982.

24) Pereira, L., Cassai, E., et al.: Variability in the structural polypeptides of herpes simplex virus 1 strains: Potential application in molecular epidemiology. Infect Immun 13: 2112201976.

25) Buchman, T.G., Roizman, B., et al.: Restriction endonuclease fingerprinting of herpes simplex virus DNA: A novel epidemiological tool applied to a nosocomical outbreak. J Infect Dis 138: 488-498 1978.

26) Kawana, T., Chen, J.T.: Clinical and viro- 
logical aspects of female genital herpes in Japan. in Herpesvirus, clinical, pharmacological and basic aspects. Experta Medica, 1982, p 339-350.

27) Nahmias, A.J.: Clinical aspects of infection with herpes simplex virus 1 and 2. in The Human Herpes Viruses. Elsevier, New York,
1981, p 3-9.

28) Miller, J.B.: Herpes simplex infection of the fingers of a dentist. J Dent Child 43: 99-102 1976.

29) Rowe, N.H., Heine, C.S., et al.: Herpetic withlow: an occupational disease of practicing dentists. JADA 105: 471-473 1982. 